\title{
Organizational Business Excellence

\section{AN INVESTIGATION OF THE IMPACT OF SOCIAL MEDIA ON BUSINESS VALUE AND FINANCIAL PERFORMANCE OF ORGANIC SKIN CARE BRANDS IN THAILAND}

\author{
Napasorn Boonpreda ${ }^{1}$ and Ximing Ruan ${ }^{2 *}$ \\ ${ }^{1,2}$ Bristol Business School, University of the West of England, Bristol, United Kingdom
}

\section{Abstract}

The adoption of social media in promoting cosmetic brands had changed the traditional approach to creating value for consumers, which subsequently improve the firms' financial performance. With the organic skincare brands, the research empirically examined to what extent and aspects the business value is shaped by social media promotions. The research findings from the quantitative analysis suggest that the business value could be created through curation, collaboration, and creation in social media marketing.

Keywords: Social Media, Cosmetic, Financial Performance, Quantitative Methods

\section{INTRODUCTION}

Cosmetics and skincare industry has always remained and still continues to be one of the most competitive industries globally. However, in the past decade, the advent and rapid growth of social media have completely transformed the long-standing cosmetics industry through the introduction of a host of new opportunities in the form of social media bots, Instagram stories, Facebook Live and Facebook/Twitter Analytics )Suresh et al. 2016. These new set of tools have provided businesses with the opportunities of launching more refined marketing campaign at either very low )in-organic( or no cost )organic( at all. This is extremely effective for small organic cosmetic brands such as Mellow Naturals, Brisuthi, Fyne and Amira, who do not have huge marketing budgets like big brands, including Estee Lauder or L'Oréal JMellow

\section{ARTICLE INFO}

Article history:

Received: 26 August 2020

Accepted: 19 October 2020

Email Addresses:

ximing.ruan@uwe.ac.uk (Ximing Ruan)

*Corresponding author
Naturals, 2019(. Social media has turned into an ideal brand discovery channel, specifically among cosmetic buyers )Valentine 2019(. social media has provided both businesses as well as consumers with a hub for engaging in more compelling and captivating conversations )Ashley \& Tuten, 2015(. The results of the study further revealed that in Thailand, more than $41 \%$ of consumers are more likely to discover new cosmetics brand or skincare products via social media ads, and $47 \%$ of consumers are more likely to do so via updates over brand's social media pages.

In past few years, the number of social media users has grown quite rapidly in Thailand; reaching 33.8 Million in 2019, amongst which a big majority )51\%( of social media users were women )Statista, 2017.. Moreover, another positive trend for organic cosmetics brands is the growth in demand of organic cosmetics products; the organic cosmetics market of Thailand is forecasted to grow by $9.4 \%$ totalling revenues of $\$ 1.29$ billion by the end of 2020 ("The ASEAN organic cosmetics," 2016(. Therefore, Thailand could be an ideal growth market for organic cosmetic brands, and social media can be 
deemed as an ideal marketing tool to target, attract, engage and convert prospects in the brand loyalists. The unique features in the Thailand cosmetic market deserve further research to explore how to achieve effective social media marketing on business value to improve firms' financial performance.

Conti )2018( points out that the experiential nature of social media has completely transformed the $\$ 200$ billion worth the global cosmetic industry. The growing popularity of influencer marketing, social media bots, live feeds and Instagram stories have turned social media platforms into ultimate marketing channels for brands, where they can not only communicate with their consumers in a more compelling manner but also with the opportunity of converting prospects into brand loyalists.

The research aims to determine the impact of social media and customer equity on an organic skincare company's finance and how it promotes building financial performance of the firm. An evaluation of the impact of social media marketing over the financial performance of organic skincare brands in Thailand will be concluded.

The objectives of the research is to determine: 1) the impact of social media on business value and how it helps in building customer equity; 2 ) the impact of social media marketing overvalue equity of organic skincare brands in Thailand; 3) how social media marketing helps in building brand equity and relationship equity; and 4) the impact of social media marketing over the financial performance of organic skincare brands in Thailand.

Big brands like L'Oréal have embraced these social media channels through creating their personal business pages. L'Oréal reportedly allocated more than $30 \%$ of its marketing budget over social media channels; an example of this could be the recently launched 'Beauty Squad' campaign; featuring some of the top beauty influencers like Patricia Bright, Victoria Magrath and Emily Canham )Team, 2017(. The influencers created videos and articles for L'Oréal's official website, and its social media pages like YouTube and Instagram, thereby enabling the brand to reach more than 5.5 Million prospective consumers already connected over these influencer accounts )Roderick, 2016(. This brand also posts videos showcasing beauty tips, make-up tutorial and skin care advice from celebrities, influencers and make-up experts; thereby creating the type of content which users are actually searching for. This has helped the brand in garnering more than 6.8 $M$ followers over Instagram, 3.5K subscribers over YouTube and more than 2 million followers over Facebook.

The number of social media users in Thailand is expected to increase from 32.1 million users in 2017 to 37 million by early 2023.

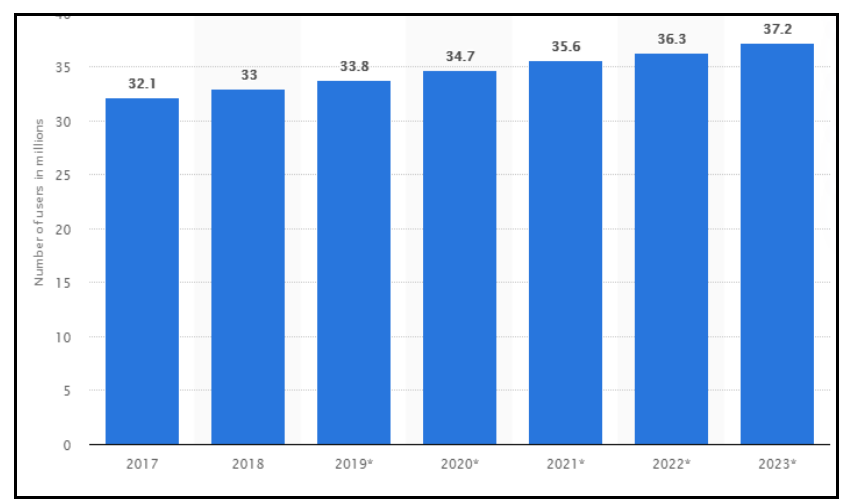

Figure 1. Number of social network users in Thailand.

Source: )Statista, 2017(.

The effective digital marketing strategy of the brand has also promoted the online sales record, according to the statistics published by Vizard )2018( L'Oréal generated around €2 Billion annually via online sales, which makes around $8 \%$ of the total revenues generated by the brand. Hence, it could be concluded that effective and intuitive social media marketing strategy of L'Oréal has not only helped the brand in building a high level of brand value/equity through posting compelling and engaging content but at the same time, it has also allowed the brand to boost its overall financial performance through offering consumers convenient online purchasing options. Similarly, other brands have also

Int'1 J. of Org. Bus. Excellence Vol. 3(2): 49 - 64 (2020) 
launched similar marketing champions through online platforms.

\section{LITERATURE REVIEW}

\section{Social media marketing}

Tuten and Solomon )2017( define social media as a combination of web-based services which offers individuals

(i) the ability to construct their public profile within a confined system

(ii) communicate and converse with a group of other users with whom they are connected via social media sites and

(iii) View and traverse their connections within the systems.

These applications facilitate the process of development and interchanging of usergenerated content. Social media has turned into an ideal platform for consumers searching for information with respect to a product or services that they intend to purchase in the future, and it plays the role of a facilitator or influencers of consumer purchase intention, due to the fact that majority of consumer make the decision to purchase a product or services after reading customer reviews, feedbacks, ratings )Varkaris and Neuhofer 2017(. On the other hand, firms can use these social media channels to achieve its multiple organisation objectives such as; branding, problem-solving, marketing, customer services, PR and etc. Hajli 2015( points out the that development of social media platforms has boosted interconnectivity between brands and consumers, while at the same time it has helped the brand in reaching mass consumers while keeping the costs of marketing optimal.

Social Media Marketing is a form of internet marketing which involves the curation, publishing and sharing of brand-specific content over social networking sites with the aim of achieving the overall branding and marketing objectives of the firm )Dwivedi et al. 2015(. Consumers today are spending a big portion of their time over social media sites like Facebook, Twitter and Instagram searching for information with respect to products and services they intend to purchase JStephen,
2016(. The information posted over social media sites is considered to be more trustworthy, authentic and reliable, due to the fact that consumers usually share their reviews, ratings and feedbacks with respect to a certain product or service from a brand which is considered as a more trustworthy metric, as compared to the brand owned advertise or creative )Turcotte et al. 2015. Thus, social media sites have turned "reference group" and a major influencer of consumer decision. Thereby it has become an ideal platform to attract prospects towards the brand, and turn these prospects clients into brand loyalists )Kwon et al. 2017(.

\section{Overview of organic cosmetics market}

In past few years' consumers have become more concerned with respect to the environment, due to which they prefer to purchase products from brands that use ecofriendly and sustainable production methods )Ghazali et al. 2017(. This trend has also led towards a major shift in demand for organic products, as consumers are increasingly demanding eco-friendly, animal friendly and ethically sourced skincare products. This in turn has led towards the expansion of global organic cosmetics market size, which according to current estimation is worth $\$ 13.33$ billion. Whereas, the market is forecasted to grow by a CAGR of $8.52 \%$ totalling $\$ 7.15$ billion by the end of 2024 )Market Watch, 2019(.

A major factor driving growth in demand of organic products is social media, as consumers, celebrities and influencers share their personal reviews with respect to their favourite organic cosmetic and skincare products, and their benefits which in turn urges their followers to become socially conscious and purchase nonsynthetic, naturally and ethically sourced cosmetic products. A recent survey conducted by Aisyah 12017) found that the growth in demand of organic products has led towards a substantial increase in the availability of these products across multiple distribution channels like malls, drugstores and supermarkets. Furthermore, the growth of social media and ecommerce has further contributed to the

Int'1 J. of Org. Bus. Excellence Vol. 3(2): 49 - 64 (2020) 
growth of this segment.

Thailand continues to remain as the fastestgrowing organic cosmetics market in ASEAN, as the Thai cosmetics market alone accounted for more than $30 \%$ of the revenue share in the year 2015 , and was valued at $\$ 809$ million. The Thai beauty market is forecasted to sustain its growth momentum, mostly due to the growth of social media and an increase in purchasing power. According to the statistics published by Future Marketing Insights )2015( the Thai organic cosmetics market is expected to grow by CAGR of $9.4 \%$, generating total revenues worth $\$ 1.29$ billion by the end of 2020 , which is quite remarkable and shows the phenomenal growth potential of the market.

\section{Customer equity}

Customer Equity could simply be defined as the value of potential future revenue generated by a firm's clients during the firm's entire lifetime. According to Aisyah )2017( value which a customer brings to a firm is not just restricted to profits, but it is actually the total profit that a customer provides the firm over a period of time. Yuan et al. )2016( proposed three factors which drive customer equity for a firm, these include relationship equity, value equity and brand equity.

\section{Value equity}

Value equity could simply be defined as the objective assessment of a consumer with respect to a brand's utility. It is basically the perception of what a customer has actually given up and what he or she has accepted. Hossain et al. )2017( point out that three basic factors that influence value equity; quality, price and convenience.

\section{Brand equity}

Keller and Brexendorf )2017( define brand equity as the intangible and subjective assessment of a brand by a consumer. Firms can build brand equity for its products or services through boosting their product quality, reliability, and through making their product easily recognizable and memorable. According to Liao et al.
)2017(, brand equity is extremely essential for low involvement purchases such as washing powder, diapers or soap.

\section{Relationship equity}

Relationship equity could simply be defined as the emotional bond between the customer and the brand. The keystone's using which firms can foster and nurture relationship quality are loyalty programs, affinity programs, discounts, and special recognition.

\section{Impact of social media marketing over financial performance of firms}

Wang and Kim 12017) advocate that the adoption of social media directly influences the performance of a firm, which is supported by Kumar et al. )2017(. Kohler and Chesbrough 2019( proposed that there are three major elements in fostering and nurturing customerbrand collaboration through a social media marketing perspective.

\section{Curation}

It could be defined as the process of filtering, reviewing, rating, or sorting content online. Curation is basically the process of making content useful for other users present over social media platforms. Pelet et al. )2015( stated that curation is an essential social action since it facilitates, shapes and prune signal to noise ratio over digital platforms, brands can use curation to encourage the customer to participate and become an active member in the community.

\section{Creation}

Content creation is basically the process of creating unique content )Karjaluoto et al. 2015(.

\section{Collaboration}

Social media has emerged into an ideal platform for the creation and fostering of collaboration between the customers and the brand. 


\section{Conceptual framework}

Figure 2 provides an illustration of the conceptual framework which the researcher has designed for the research.

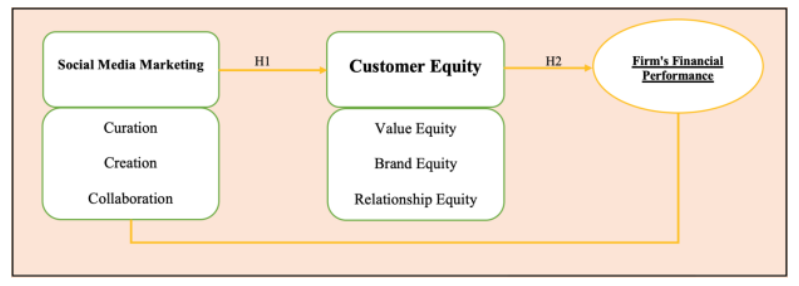

Figure 2. Conceptual Framework

The model will be empirically tested based on the hypotheses.

$\mathrm{H}_{1}$ : There relationship between social media marketing and financial performance of the Organic Skin Care firm in Thailand, is significant.

- $\mathrm{H}_{1 \mathrm{a}}$ : There exists a positive relationship between curation and the financial performance of the Organic Skin Care firm in Thailand.

- $\mathrm{H}_{1 \mathrm{~b}}$ : There exists a positive relationship between creation and financial performance of the Organic Skin Care firm in Thailand.

- $\mathrm{H}_{1 \mathrm{c}}$ : There exists a positive relationship between collaboration and financial performance of Organic Skin Care firm in Thailand.

$\mathrm{H}_{2}$ : There relationship between customer equity and financial performance of the Organic Skin Care firm in Thailand, is significant.

- $\mathrm{H}_{2 \mathrm{a}}$ : There exists a positive relationship between value equity and financial performance of the Organic Skin Care firm in Thailand.

- $\mathrm{H}_{2 \mathrm{~b}}$ : There exists a positive relationship between brand equity and financial performance of Organic Skin Care firm in Thailand.

- $\mathrm{H}_{2 \mathrm{c}}$ : There exists a positive relationship between relationship equity and financial performance of the firm
$\mathrm{H}_{3}$ : Social Media Marketing has a significant impact on the customer equity of an organic cosmetic firm in Thailand.

\section{MATERIALS AND METHODS}

The research employs a positivist approach to verify the causal relationship between a brand's social media influence and its business value amongst a considerably large sample size population of $386-400$. Assessing the relationship will involve the comparison of statistical data on the brand's value and financial performance )dependent variables( and its correlation to the various other forms of marketing identity including social media )independent variables(. Establishing the relationship between variables using logic and statistical measurement is symptomatic of this papers' positivist research paradigm )Khaldi, 2017.

\section{Research approach selection}

In keeping with the chosen positivist research paradigm, the focus on quantitative data has been the foremost priority as the variables stated above can be quantified and numerically evaluated. The financial performance )dependent variable( and business value )based on customer equity( measured by various cost-benefit analyses and productivity ratios and the various independent variables measured through the use of a survey questionnaire and is likely to prove whether the aforementioned hypotheses are true or false. This follows a deductive reasoning process that affirms our quantitative research method (Sondhi \& Wilson, 2011(.

The following are the two conditions required for valid research participant entry.

- All participants must be familiar with social media, the minimum conditions of which can be denoted by the participant's ownership of at least one social media account.

- All participants are required to be a user/buyer of a cosmetic product as the minimum condition of which can be 
denoted through the participant's purchase of at least one cosmetic product or at the least be employed in the section of cosmetics sector.

In implementing these conditions, the research's initial sample size of the entire Thai population can be streamlined into manageable segments of the Thai population that are closely tied with the variables stated in the research approach. Also taking into consideration the formula to calculate the minimum optimal sample size, factors such as margin of error, confidence interval and total population can be represented in the following equation.

Minimum sample size

$$
\frac{\frac{z^{2} \times p(1-p)}{e^{2}}}{1+\left(\frac{z^{2} \times p(1-p)}{e^{2} N}\right)}
$$

$\mathrm{N}=$ population size $\cdot \mathrm{e}=$ Margin of error )percentage in decimal form $(\bullet z=z$-score

The z-score is the number of standard deviations a given proportion is away from the mean. Surveymonkey )2019( provides a tabulated set of values of each $z$ score corresponding to a range of confidence levels that would be considered statistically reliable (Table 1 ).

Table 1. The Confidence Interval of Z-Score

\begin{tabular}{ll}
\hline Desired confidence level & z-score \\
\hline $80 \%$ & 1.28 \\
\hline $85 \%$ & 1.44 \\
\hline $90 \%$ & 1.65 \\
\hline $95 \%$ & 1.96 \\
\hline $99 \%$ & 2.58 \\
\hline
\end{tabular}

According to the data from the World Bank in 2017, the Thai population at the time was close to 70 million. Entering the stated values, and the population size of Thailand in 2017 into the formula with the desired confidence interval of $95 \%$, the appropriate sample size is set at 385 .

The numerical data format of this research has produced raw data that are coded into the SPSS program that will compute factor analysis calculations of the data.

The adoption of a quantitative research approach has had its immediate results within a short span of time but the difficulty of the codifying of research data results has been cumbersome and tallying all these results into the SPSS framework has been consuming. The advantages, however, outweigh the disadvantages as the established drawbacks of less controllable research environment is remedied by the readily editable and customisable survey form and the online apprehension of participants further inquiring about the survey questions. The issue of improper representation of the sample in qualitative research )Younus, 2014( is to some extent addressed by thorough screening and demographic questions to distil the appropriate target segments. The limitations of outcomes in quantitative data )Simon, 2011( has been partially rectified by the number of variables stated in the hypotheses and the inclusion of demographic influences as well in the research analysis.

\section{Reliability test - Cronbach Alpha}

In this research, the reliability test was proceeded to analyze the internal consistency of the overall collected data. The internal consistency of a data is calculated to assess, whether or not, the overall dataset presents a common result as seen in Table 2 .

Table 2. Cronbach Alpha Reliability Test

\begin{tabular}{lcc}
\hline Variable & Item & Cronbach's Value \\
\hline Curation & 3 & 0.873 \\
\hline Creation & 3 & 0.731 \\
\hline Collaboration & 3 & 0.785 \\
\hline Value Equity & 3 & 0.788 \\
\hline Brand Equity & 3 & 0.891 \\
\hline
\end{tabular}

Int'1 J. of Org. Bus. Excellence Vol. 3(2): 49 - 64 (2020) 
An Investigation of the Impact

\begin{tabular}{lcc}
\hline Relationship Equity & 3 & 0.880 \\
\hline $\begin{array}{l}\text { Firm Financial } \\
\text { performance }\end{array}$ & 4 & 0.731 \\
\hline
\end{tabular}

In Table 2, it was seen that the Cronbach alpha test showcased an alpha value above 0.70 . The data collected on curation, brand equity, and, relationship equity depicted a high internal consistency value. However, other existing data also depicts a value above 0.65 . As per the methodological statement, the Cronbach alpha value greater than 0.65 is considered to provide an internally consistent data. Therefore, this research validates the data conformity to provide consistent research.

\section{Data validity and screening test}

To assess that the collected data is collected from a valid population, this research presents two screening question. The two research questions (Table 3 and 4) include the assessment of skincare products and the use of social media.

Screening Question 1: Have you purchased organic skin-care products?

Table 3. Screening Question 1

\begin{tabular}{lllll}
\hline & & Frequency & Percent & Valid Percent \\
\hline Valid & YES & 398 & 100.0 & 100.0 \\
\hline
\end{tabular}

Screening Question 2: Do you use social media?

Table 4. Screening Question 2

\begin{tabular}{ccccc}
\hline & & Frequency & Percent & Valid Percent \\
\hline Valid & YES & 398 & 100.0 & 100.0
\end{tabular}

From the data screening test, a total of 398 responses were selected. These 398 data comprised of unique demographics based on age, gender, occupation, and, education which is listed in Table 5.

Table 5. Gender Composition

\begin{tabular}{ccc}
\hline Gender & Frequency & Valid Percent \\
\hline Female & 168 & $42.20 \%$ \\
\hline Male & 230 & $57.80 \%$ \\
\hline Total & 398 & $100 \%$ \\
\hline
\end{tabular}

\section{Data analysis}

Hypothesis 1: Social Media Marketing and Financial Performance

The first hypothesis is tested via the correlation between the dependent variable firm's financial performance with the independent variable, ) $a$ ( curation, $) b$ (creation, and, )c( collaboration A Pearson correlation test proceeds between the dependent and independent variable.

\section{Hypothesis 1)a( test}

There exists a positive relationship between curation and the financial performance of the Organic Skin Care firm in Thailand.

Table 6. Hypothesis 1(a) Test

\begin{tabular}{lcl}
\hline \multicolumn{2}{l}{ Pearson Correlation ) Curation( } & Remarks \\
\cline { 1 - 1 } $\begin{array}{l}\text { Pearson } \\
\text { Correlation }\end{array}$ & 0.22 & \\
\cline { 1 - 2 } Sig )2-Tailed( & 0.00 & \\
\cline { 1 - 2 } $\mathbf{N}$ & 398 & \\
\hline
\end{tabular}

The first test suggests that the relationship between the curation factor, and, the financial performance have a positive correlation (Table 6). The significance level of 0.01 is considered in this research. It can be seen that the significant correlation is 0.00 which suggests a lower value compared to 0.01 . Added to that, there is a $22 \%$ correlation or explanation between the two variables.

\section{Hypothesis 1)b(test}

There exists a positive relationship between creation and financial performance of the Organic Skin Care firm in Thailand.

Table 7. Hypothesis 1(b) Test 
Boonpreda, Napasorn and Ruan, Ximing

\begin{tabular}{lcc}
\hline \multicolumn{2}{l}{ Pearson Correlation )Creation( } & Remarks \\
\hline Pearson Correlation & 0.30 & \multirow{2}{*}{ Sig ) 2 Tailed $(<0.01$} \\
\cline { 1 - 1 } Sig )2-Tailed( & 0.00 & \\
\cline { 1 - 1 } $\mathrm{N}$ & 398 & \\
\hline
\end{tabular}

Hypothesis 1) $b$ ( suggests that there is a significant relationship between the creation factor of social media advertising and the financial performance of the firm. According to the respondents, the creation factor tends to provide a significant level of organizational effectiveness and develops a positive influence on financial performance. The correlation level is stated at 0.30 (Table 7).

\section{Hypothesis 1)c( test}

There exists a positive relationship between collaboration and financial performance of the Organic Skin Care firm in Thailand.

Table 8. Hypothesis 1(c) Test

\begin{tabular}{lcl}
\hline \multicolumn{2}{l}{ Pearson Correlation (Collaboration) } & Remarks \\
\cline { 1 - 1 } Pearson Correlation & 0.25 & \\
\cline { 1 - 2 } Sig (2-Tailed) & & \\
\cline { 1 - 1 } $\mathrm{N}$ & 0.00 & \\
\end{tabular}

For the test hypothesis 1)c(, it could be seen that the relationship is positive between the collaboration factor and the firm's financial performance (Table 8). The collaboration factor has a medium variability on the firm's financial performance based on the results.

\section{Hypothesis 2}

Similarly, the second hypothesis is tested to find the relationship between customer equity and value, and the financial performance of the organic skincare in Thailand. In order to proceed with this test, the ANOVA tests are utilized. The ANOVA regression is assessed to identify the relationship between how the ANOVA test results predict the financial performance of the firm based on customer equity.

\section{Hypothesis 2)a( Test}

There exists a positive relationship between value equity and financial performance of the Organic Skin Care firm in Thailand.

Table 9. Hypothesis 2(a) Test

\begin{tabular}{lll}
\hline Model Summary & & \\
\hline $\mathrm{R}$ & R-Squared & Adjusted R-Squared \\
\hline 0.360 & 0.130 & 0.128 \\
\hline $\begin{array}{ll}\text { Regression (ANOVA) } \\
\text { F-value }\end{array}$ & 59.127 \\
\hline Regression (ANOVA) Sig. & 0.000 \\
\hline Co-efficient Value & 0.360 \\
\hline
\end{tabular}

Based on the findings above, it can be seen that the dependent variable )value equity( tends to have a positive influence on an organic cosmetic firm's financial performance. That said, the dependent variable explains $36 \%$ of the total data acquired in the research (Table 9).

\section{Hypothesis 2)b(test}

There exists a positive relationship between brand equity and financial performance of Organic Skin Care firm in Thailand.

Table 10. Hypothesis 2(b) Test

\begin{tabular}{lll}
\hline \multicolumn{2}{l}{ Model Summary } & \\
\hline $\mathrm{R}$ & R-Squared & Adjusted R-Squared \\
\hline 0.315 & 0.099 & 0.097 \\
\hline $\begin{array}{l}\text { Regression (ANOVA) } \\
\text { F-value }\end{array}$ & 43.622 \\
\hline Regression (ANOVA) Sig. & 0.000 \\
\hline Co-efficient Value & 0.315 \\
\hline
\end{tabular}

The hypothesis test 2)b( suggests that there is a $31.5 \%$ explanatory capacity of brand equity on a firm's financial performance. Similarly, a positive relationship is depicted in the findings (Table 10). 
Hypothesis 2)c( test

There exists a positive relationship between relationship equity and financial performance of the firm.

Table 11. Hypothesis 2(c) Test

\begin{tabular}{ll}
\hline \multicolumn{2}{l}{ Model Summary } \\
\hline $\mathrm{R} \quad \mathrm{R}$-Squared & Adjusted R-Squared \\
\hline $0.269 \quad 0.072$ & 0.070 \\
\hline $\begin{array}{l}\text { Regression (ANOVA) } \\
\text { F-value }\end{array}$ & 30.785 \\
\hline $\begin{array}{l}\text { Regression (ANOVA) Sig. } \\
\text { Co-efficient Value (Beta) }\end{array}$ & 0.000 \\
\hline
\end{tabular}

Based on the research findings, relationship equity has a positive influence on the financial performance of the firm. That said, however, this factor has a lower explanatory capacity at $26.90 \%$. That said, however, the variable poses a significant relationship (Table 11).

\section{Hypothesis 3}

The third and final hypothesis is designed to test the impact of social media marketing on the customer equity of the users. That said, a correlation approached is utilized in this research to identify how both variables are inter-related. A significance level of 0.01 is subjugated in this research.

\section{Correlations}

Table 12. Hypothesis 3 Test

\begin{tabular}{|c|c|c|c|c|c|c|c|}
\hline & & Curation & Creation & Collaboration & V.E. & $B, E$ & R.E. \\
\hline \multirow[t]{3}{*}{ Curation } & $\begin{array}{l}\text { Pearson } \\
\text { Correlation }\end{array}$ & 1 & $0.203^{* *}$ & $0.167^{* *}$ & $0.266^{* *}$ & $0.199^{* *}$ & $0.222^{* *}$ \\
\hline & Sig. )2-tailed( & & 0.000 & 0.001 & 0.000 & 0.000 & 0.000 \\
\hline & $\mathrm{N}$ & 398 & 398 & 398 & 398 & 398 & 398 \\
\hline \multirow[t]{3}{*}{ Creation } & $\begin{array}{l}\text { Pearson } \\
\text { Correlation }\end{array}$ & $0.203^{* *}$ & 1 & $0.152^{* *}$ & $0.409^{* *}$ & $0.306^{* *}$ & $0.288^{* *}$ \\
\hline & Sig. )2-tailed( & 0.000 & & 0.002 & 0.000 & 0.000 & 0.000 \\
\hline & $\mathrm{N}$ & 398 & 398 & 398 & 398 & 398 & 398 \\
\hline \multirow[t]{3}{*}{ Collaboration } & $\begin{array}{l}\text { Pearson } \\
\text { Correlation }\end{array}$ & $0.167^{* *}$ & $0.152^{* *}$ & 1 & $0.181^{* *}$ & $0.243^{* *}$ & $0.287^{* *}$ \\
\hline & Sig. )2-tailed( & 0.001 & 0.002 & & 0.000 & 0.000 & 0.000 \\
\hline & $\mathrm{N}$ & 398 & 398 & 398 & 398 & 398 & 398 \\
\hline \multirow{3}{*}{$\begin{array}{l}\text { V.E. } \\
\text { (Value } \\
\text { Equity) }\end{array}$} & $\begin{array}{l}\text { Pearson } \\
\text { Correlation }\end{array}$ & $0.266^{* *}$ & $0.409^{* *}$ & $0.181^{* *}$ & 1 & $0.226^{* *}$ & $0.310^{* *}$ \\
\hline & Sig. )2-tailed( & 0.000 & 0.000 & 0.000 & & 0.000 & 0.000 \\
\hline & $\mathrm{N}$ & 398 & 398 & 398 & 398 & 398 & 398 \\
\hline \multirow{3}{*}{$\begin{array}{l}\text { B.E. } \\
\text { (Brand } \\
\text { Equity) }\end{array}$} & $\begin{array}{l}\text { Pearson } \\
\text { Correlation } \\
\end{array}$ & $0.199^{* *}$ & $0.306^{* *}$ & $0.243^{* *}$ & $0.226^{* *}$ & 1 & $0.241^{* *}$ \\
\hline & Sig. )2-tailed( & 0.000 & 0.000 & 0.000 & 0.000 & & 0.000 \\
\hline & $\mathrm{N}$ & 398 & 398 & 398 & 398 & 398 & 398 \\
\hline \multirow{3}{*}{$\begin{array}{l}\text { R.E. } \\
\text { (Relationship } \\
\text { Equity) }\end{array}$} & $\begin{array}{l}\text { Pearson } \\
\text { Correlation }\end{array}$ & $0.222^{* *}$ & $0.288^{* *}$ & $0.287^{* *}$ & $0.310^{* *}$ & $0.241^{* *}$ & 1 \\
\hline & Sig. )2-tailed( & 0.000 & 0.000 & 0.000 & 0.000 & 0.000 & \\
\hline & $\mathrm{N}$ & 398 & 398 & 398 & 398 & 398 & 398 \\
\hline
\end{tabular}

Based on the correlation analysis in Table 12 , it is clear that the sub-variables of social media marketing and customer equity tends to be significant. Each of the variable ha a

Int'1 J. of Org. Bus. Excellence Vol. 3(2): 49 - 64 (2020) 
significant result. However, it can be seen that collaboration and creation has the least correlation, while, value equity and equity has the highest correlation between each other. Similarly, other existing variables also depict a positive correlation between each other. There are no other insignificant correlation variables in the study.

\section{RESULTS AND DISCUSSIONS}

Summary of the findings

It can be concluded that all of the presented findings depict a positive relationship between the outright suggested variables on the financial performance of the firm. The independent variables of this research include the social media marketing factors including: (a) curation, (b) creation, (c) collaboration, (d) value equity, (e) brand equity, and (f) relationship equity. Based on the findings, this research can proceed with the assessment via data triangulation. The data triangulation refers to the triangulate the research between consumers choice based on social media marketing and consumer equity, along with the firm's financial performance. A summary of the findings are shown in Table 13.

Table 13. Hypothesis Summary

\begin{tabular}{|c|c|c|}
\hline Hypothesis & Remarks & Literature \\
\hline $\begin{array}{l}\text { There exists a positive relationship } \\
\text { between curation and financial } \\
\text { performance of the Organic Skin } \\
\text { Care firm in Thailand. }\end{array}$ & $\begin{array}{l}\text { Hypothesis } \\
\text { Accepted }\end{array}$ & $\begin{array}{l}\text { Accepted } \\
\text { Pelet et al. )2015( }\end{array}$ \\
\hline $\begin{array}{l}\text { There exists a positive relationship } \\
\text { between creation and financial } \\
\text { performance of the Organic Skin } \\
\text { Care firm in Thailand }\end{array}$ & $\begin{array}{l}\text { Hypothesis } \\
\text { Accepted }\end{array}$ & $\begin{array}{l}\text { Accepted } \\
\text { Karjaluoto et al. } 2015\end{array}$ \\
\hline $\begin{array}{l}\text { There exists a positive relationship } \\
\text { between collaboration and } \\
\text { financial performance of the } \\
\text { Organic Skin Care firm in Thailand. }\end{array}$ & $\begin{array}{l}\text { Hypothesis } \\
\text { Accepted }\end{array}$ & $\begin{array}{l}\text { Accepted } \\
\text { Zhu et al. } 2015\end{array}$ \\
\hline $\begin{array}{l}\text { There exists a positive relationship } \\
\text { between value equity and } \\
\text { financial performance of the } \\
\text { Organic Skin Care firm in Thailand. }\end{array}$ & $\begin{array}{l}\text { Hypothesis } \\
\text { Accepted }\end{array}$ & $\begin{array}{l}\text { Accepted } \\
\text { Hossain et al. )2017( } \\
\text { Zhang et al. )2016( }\end{array}$ \\
\hline $\begin{array}{l}\text { There exists a positive relationship } \\
\text { between brand equity and } \\
\text { financial performance of Organic } \\
\text { Skin Care firm in Thailand. }\end{array}$ & $\begin{array}{l}\text { Hypothesis } \\
\text { Accepted }\end{array}$ & $\begin{array}{l}\text { Accepted } \\
\text { Keller and Brexendorf )2017( } \\
\text { Luo )2019( }\end{array}$ \\
\hline $\begin{array}{l}\text { There exists a positive relationship } \\
\text { between relationship equity and } \\
\text { financial performance of the firm }\end{array}$ & $\begin{array}{l}\text { Hypothesis } \\
\text { Accepted }\end{array}$ & $\begin{array}{l}\text { Accepted } \\
\text { Liao et al. )2017( } \\
\text { Lee et al. 2018( } \\
\text { Cheng et al. } 2019\end{array}$ \\
\hline $\begin{array}{l}\text { There exists a positive relationship } \\
\text { between social media marketing } \\
\text { and customer equity of the } \\
\text { Organic Skin Care firm in Thailand. }\end{array}$ & $\begin{array}{l}\text { Hypothesis } \\
\text { Accepted }\end{array}$ & $\begin{array}{l}\text { Accepted } \\
\text { Varkaris and Neuhofer } 2017 \\
\text { Stephen, 2016 } \\
\text { Yuan et al. )2016( }\end{array}$ \\
\hline
\end{tabular}

\section{Discussion of the primary findings}

Based on the research by Tuten and Solomon 12017(, it was found that the social media is a combination of various web-based activities that allows consumers to develop a profile and connect to brands and other consumers. The notion of Web 2.0 has introduced numerous platform like Facebook, Instagram, Twitter etc., that benefits the overall consumers and social media marketers. 
In this research, the findings indicate that majority of the users were using Instagram at $51.30 \%$. Added to that, other forms of social media application were only used by $43.80 \%$ of the total respondents combines. This showcases that Instagram is amidst the proliferating social media networking site that would benefit the marketers of the cosmetics industry. In addition, the research by Kaplan and Haenlein 12011 ( and the study by Felix et al., )2017( suggested that social media can basically engage consumers with micro-blogs, video-sharing application, and other engaging contents. The use of engaging content for the cosmetics industry can be proliferating over the years. A total of $92.50 \%$ of the surveyed respondents suggested that this provides value to the business, and over $72.10 \%$ of respondents were engaged with the social media application. Since a large portion of the consumers have spent on online marketing, and online commerce - these consumers are focused on publishing, sharing, and developing the interest of brand-specific consumers to engage with their page and their post. That said, the research by Turcotte et al., )2015( further suggested that the consumers tend to share reviews, and post reviews that can develop the metrics of trustworthiness for brands. This also tends to build brand value in the social media platform.

The first pillar, content curation is presented by Pelet et al. )2015( as essential since it encourages the consumer to interact with the brand. The findings of this research demonstrated that there was a positive relationship between the curation factor and the financial performance of a business.

The second pillar is the creation. By definition, creation is the one in which a company will create attractive content for its customers defined by Karjaluoto et al. 12015). Studies have shown that consumers are sensitive to quality content. This hypothesis was confirmed since the respondents declared that quality content positively influences their buying habits.

The last pillar is collaboration. Research by Zhu et al. 2015 suggests that brands must maintain a privileged link with customers, and interact with them regularly. We can also deduce that thanks to research, collaboration has a positive influence on the financial performance of a company. Studies by Zhang et al. )2016(, Keller \& Brexendorf )2017( or Liao et al. )2017(, other factors such as value equity, relationship equity and brand equity are assets for the development of a business.

The findings of this research indicated that there was a positive relationship between these three factors and the financial performance of a business. A good example of this phenomenon is the cosmetic brand Glossier. It is one of the many brands whose social media are an integral part of their marketing strategies. Studies by Schiffer )2018( have shown that consumers, the vast majority of whom are women, pay attention to their beauty and makeup products. The Glossier brand understood that reviews and opinions were essential for their customers. Glossier understood and made it possible by using certain packaging colours, or even stickers have shown studies conducted by Maril )2019(. By nurturing and maintaining relationships with customers, the results of studies conducted by Beltran 12019( shows that Glossier had reached a value of 1.2 billion, and attracted more than 1 million new customers, which is considerable for a company that is only 8 years old.

Concluding this discussion, it can be stated that the research develops as a foundation of the relationship between the consumer's perceived financial performance of the firm is positive based on the social media marketing and the customer equity. Added to that, this research also suggests that brands that are engaged in the successful pursuance of social media can support brand value development and the development of customer equity.

\section{CONCLUSIONS}

The significance of the research and the findings revolve around the cosmetics industry. Cosmetics industry are one of the important source of revenue for Thailand, as well as, with the outlying development of the organic

Int'1 J. of Org. Bus. Excellence Vol. 3(2): 49 - 64 (2020) 
cosmetic industry - there is a need for the market review. That said, the findings suggest that - firstly, the research submits to the development of the cosmetics industry, and how consumers perceive the development of financial development based on customer equity and the development of social media marketing. Firstly, the findings suggest a positive lyet, a low-moderate strength correlation( between social media marketing and the firm's financial performance. This suggests that marketers should emphasize on developing their social media marketing context. Added to that, the marketers should also focus on pursuing the development of customer equity, as customer equity contributes to positive financial performance as well. The positive development of financial performance, based on the customer perspective, tends to provide a positive contribution to the research. Added to that, the relationship between customer equity and social media marketing is positive. Therefore, social media marketing establishes as the foundation to develop customer equity, as well as, develop the financial performance of the firm. The marketers that are engaged in a substantial proceeding of the growth a perceived performance of a firm are highly likely to pursue a suitable content strategy in social media marketing - emphasizing on curation, collaboration, and creation. Similarly, proper development of customer equity, as well as, emphasizing on stakeholder's equity can support the development of the financial performance of the firms. That said, the findings of this research are also important for the understanding of the researcher.

\section{REFERENCES}

Aisyah, M. )2017(. Consumer demand on halal cosmetics and personal care products in Indonesia. Al-Iqtishad Journal of Islamic Economics, 9)1(, 125-142. https://doi.org/10.15408/aiq.v9i1.1867

Ajayi, V. )2017(. Primary Sources of Data and Secondary Sources of Data. PDF

Ashley, C. and Tuten, T. )2015(. Creative strategies in social media marketing: An exploratory study of branded social content and consumer engagement. Psychology $\&$ Marketing, 32)1(, 15-27. https://doi.org/10.1002/mar.20761

Beltran, L. )2019(. Online beauty brand Glossier valued at $\$ 1.2$ billion. Retrieved on 20 October 2019 from: https://www.crainsnewyork.com/retailapparel/online-beauty-brand-glossiervalued-12-billion

Cheng, Y. Y., Tung, W. F., Yang, M. H. and Chiang, C. T. )2019(. Linking relationship equity to brand resonance in a social networking brand community. Electronic Commerce Research and Applications, 35.

Conti, E. )2018(. The Experiential Approach in the Cosmetics Industry: The Eva Garden Case Study. In The Experience Logic as a New Perspective for Marketing Management, pp. 187-204. Springer, Cham.

Crets, S. )2018(. Beauty retailers grow US online sales $24 \%$. Retrieved on 20 October 2019 from: https://www.digitalcommerce360.com/a rticle/beauty-ecommerce-sales/

Dwivedi, Y. K., Kapoor, K. K. and Chen, H. )2015(. Social media marketing and advertising. The Marketing Review, 15)3(, 289-309.

https://doi.org/10.1016/j.jretconser.201 7.11.001

Felix, R., Rauschnabel, P. A. and Hinsch, C. 2017(. Elements of strategic social media marketing: A holistic framework. Journal of Business Research, 70, 118-126. https://doi.org/10.1016/j.jbusres.2016.0 5.001

Future Marketing Insights. 12015(. ASEAN Organic Cosmetics Market: Thailand, Indonesia, and Philippines Largest Markets. Retrieved on 20 October 2019 from: http://industrial.embeddedcomputing.com/news/asean-indonesiaphilippines-largest-markets/

Ghazali, E., Soon, P. C., Mutum, D. S. and Nguyen, B. )2017(. Health and cosmetics: Investigating consumers' values for 
buying organic personal care products. Journal of Retailing and Consumer Services, 39, 154-163. https://doi.org/10.1016/j.jretconser.201 7.08.002

Hajli, N. )2015(. Social commerce constructs and consumer's intention to buy. International Journal of Information Management, 35)2(, 183-191.

Hossain, T. M. T., Akter, S., Kattiyapornpong, U., \& Wamba, S. F. )2017(. The impact of integration quality on customer equity in data driven omnichannel services marketing. Procedia Computer Science, 121, 784-790.

Kaplan, A. M., \& Haenlein, M. )2011(. Two hearts in three-quarter time: How to waltz the social media/viral marketing dance. Business Horizons, 54)3(, 253-263.

Karjaluoto, H., Ulkuniemi, P., Huotari, L., Saraniemi, S., \& Mäläskä, M. )2015(. Analysis of content creation in social media by B2B companies. Journal of Business \& Industrial Marketing.

Keller, K. L., \& Brexendorf, T. O. )2017(. Measuring brand equity. Handbuch Markenführung, pp.1-32.

Khaldi, K. )2017( Quantitative, Qualitative or Mixed Research: Which Research Paradigm to Use? PDF

Kim, A. J., \& Johnson, K. K. )2016(. Power of consumers using social media: Examining the influences of brand-related usergenerated content on Facebook. Computers in Human Behavior, 58, pp. 98-108.

Kohler, T., \& Chesbrough, H. )2019(. From collaborative community to competitive market: the quest to build a crowdsourcing platform for social innovation. R\&D Management, 49)3(, 356-368.

Kumar, V., Choi, J. B., \& Greene, M. )2017(. Synergistic effects of social media and traditional marketing on brand sales: capturing the time-varying effects. Journal of the Academy of Marketing Science, 45)2(, 268-288.
Kwon, E., Ratneshwar, S., \& Thorson, E. )2017(. Consumers' Social Media Advocacy Behaviors Regarding Luxury Brands: An Explanatory Framework. Journal of Interactive Advertising, 17)1(, 13-27.

Lee, S. L., Namkung, Y. and Yoon, H. H. )2018(. A Study on the Effect of Customer Equity on Behavioral Intentions: Moderating Effect of Restaurant Type. Culinary Science \& Hospitality Research, 24)2(, 5162.

Liao, Y. K., Wu, W. Y., Amaya Rivas, A. A. and Lin Ju, T. )2017(. Cognitive, experiential, and marketing factors mediate the effect of brand personality on brand equity. Social Behavior and Personality: an international journal, 45)1(, 1-18.

Luo, J. 12019(. The Impact of Celebrity Endorsement Advertising Frequency on Brand Equity among Idolaters and Nonidolaters: A Study of the Chinese Cosmetics Market.

Maril, M. )2019( 6 Brands Like Glossier With Cool, Simple, \& Affordable Products. Retrieved on 20 October 2019 from: https://www.thezoereport.com/p/6brands-like-glossier-with-cool-simpleaffordable-products-18233364

Market Watch. )2019(. Global Organic Skin Care Products Market Share, Size 2019: Industry Segmentation, Trend, Competitors, Growth, Up and Down Stream Industry Analysis and Forecast Details for 2024 | Market Reports World. Retrieved on 20 October 2019 from: https://www.marketwatch.com/pressrelease/global-organic-skin-careproducts-market-share-size-2019industry-segmentation-trendcompetitors-growth-up-and-downstream-industry-analysis-and-forecastdetails-for-2024-market-reports-world2019-07-15

Mellow Naturals. )2019(. 7 Thai Beauty Brands You Need To Know. Retrieved on 20 October 2019 from: https://th.mellownaturals.com/blogs/me llowskincare/7-thai-beauty-brands-youneed-to-know 
Pelet, J. E., Pratt, M. A. and Fauvy, S. )2015(. MOOCs and the integration of social media and curation tools in e-learning. In International Workshop on Learning Technology for Education in Cloud, pp. 43-53. Springer, Cham.

Ravi, K. 12018). How Glossier Built a Cult Following on Social Media ]Online[. Available from: https://blog.unmetric.com/glossiersocial-media-strategy [Accessed on 20 October 2019]

Roderick, L. )2016(. L'Oréal says brands are using influencers the wrong way ]Online[. Available

from: https://www.marketingweek.com/lorealon-why-other-brands-are-usinginfluencers-the-wrong-way/ [Accessed on 20 October 2019]

Schiffer, J. )2018(. What makes a beauty brand worthy of investment in 2018. Retrieved on 20 October 2019 from: https://digiday.com/marketing/makesbeauty-brand-worthy-investment-2018/

Simon, M.K., )2011(. Dissertation and scholarly research: Recipes for success, Seattle, W.A.: Dissertation Success LLC.

Sondhi, N and Wilson, J. )2011(. Essentials of Business Research: A Guide to Doing Your Research Project. New Delhi: SAGE Publications India Pvt Ltd, 2010, 316. Global Business Review, 12(2), 343-344. https://doi.org/10.1177/0972150911012 00211

Statista. )2017(. Number of social network users in Thailand from 2017 to 2023. Retrieved on 20 October 2019 from: https://www.statista.com/statistics/4892 30/number-of-social-network-users-inthailand/

Stephen, A. T. )2016(. The role of digital and social media marketing in consumer behavior. Current Opinion in Psychology, 10, 17-21.

Suresh, V., Chitra, M. and Maran, K. )2016(. A study on factors determining social media on cosmetic product. Journal of Pharmaceutical Sciences and Research, 8)1(, 1-5.
https://www.jpsr.pharmainfo.in/Docume nts/Volumes/vol8Issue01/jpsr08011601. pdf

SurveyMonkey )2019(. 'Sample size calculator'. Retrieved on 20 October 2019 from: https://www.surveymonkey.com/mp/sa mple-size-calculator/

Taber, K. S. )2018( The Use of Cronbach's Alpha When Developing and Reporting Research Instruments in Science Education. Research in Science Education, 48, $1273 \quad$ - 1296. https://doi.org/10.1007/s11165-0169602-2

Team, T. )2017(. L'Oreal Is Benefitting From A Higher Digital Spending. Retrieved on 20 October 2019 from: https://www.forbes.com/sites/greatspec ulations/2017/02/08/loreal-isbenefitting-from-a-higher-digitalspending/\#1ff4419a43c1

The ASEAN organic cosmetics market is set for a boom. )2016(. GIC Magazine. Retrieved on 20 October 2019 from: https://www.gcimagazine.com/marketstr ends/regions/asiapacific/The-ASEANOrganic-Cosmetics-Market-Is-Set-for-aBoom-394836721.html

Turcotte, J., York, C., Irving, J., Scholl, R. M. and Pingree, R. J. $\quad$ 2015(. News recommendations from social media opinion leaders: Effects on media trust and information seeking. Journal of Computer-Mediated

Communication, 20)5(, 520-535. https://doi.org/10.1111/jcc4.12127

Tuten, T. L. and Solomon, M. R. )2017(. Social Media Marketing. New Delhi: SAGE.

Valentine, O. 12019(. How social media is reshaping the beauty industry. Retrieved on 20 October 2019 from: https://wearesocial.com/blog/2019/07/h ow-social-media-is-reshaping-thebeauty-industry

Varkaris, E. and Neuhofer, B. 12017(. The influence of social media on the consumers' hotel decision journey. Journal of Hospitality and Tourism Technology, 8)1(, 101-118. 
https://doi.org/10.1108/JHTT-09-2016$\underline{0058}$

Vizard, S. )2018(. L'Oréal looks to drive up ecommerce sales in AR partnership with Facebook. Retrieved on 22 October 2019 from:

https://www.marketingweek.com/loreallooks-to-drive-up-ecommerce-sales-in-arpartnership-with-facebook/

Wang, Z., \& Kim, H. G. )2017(. Can social media marketing improve customer relationship capabilities and firm performance? Dynamic capability perspective. Journal of Interactive Marketing, 39, 15-26.

World Bank. )2018(. 'Thailand/Population'. Retrieved on 20 October 2019 from: https://www.google.com/publicdata/exp lore?ds=d5bncppjof8f9_\&met_y=sp_pop _totl\&idim=country:THA:VNM:JPN\&hl=e $\mathrm{n} \& \mathrm{dl}=\mathrm{en}$

Younus, M. A. F. )2014(. Flood vulnerability and adaptation to climate change in Bangladesh: A review. Journal of Environmental Assessment Policy and Management, 16(3), 35-76. https://doi.org/10.1142/S146433321450 $\underline{0240}$

Yuan, C. L., Kim, J., \& Kim, S. J. )2016( Parasocial relationship effects on customer equity in the social media context. Journal of Business Research, 69)9(, 3795-3803. https://doi.org/10.1016/j.jbusres.2015.1 2.071

Zhang, H., Liang, X. and Wang, S. )2016( Customer value anticipation, product innovativeness, and customer lifetime value: The moderating role of advertising strategy. Journal of Business Research, 69)9(, 3725-3730. https://doi.org/10.1016/i.jbusres.2015.0 $\underline{9.018}$

Zhu, Y. Q. and Chen, H. G. )2015( Social media and human need satisfaction: Implications for social media marketing. Business Horizons, 58)3(, 335345.

https://doi.org/10.1016/i.bushor.2015.0 1.006 
Boonpreda, Napasorn and Ruan, Ximing

Int'1 J. of Org. Bus. Excellence Vol. 3(2): 49 - 64 (2020) 